\title{
Synthesis and Characterization of the Polymeric Phenolic Schiff Bases Containing Aminothiazole Moiety
}

\author{
DEBASIS MOHANTY ${ }^{1 *}$, P. MOHAPATRA ${ }^{2}$ and S. SAMAL ${ }^{3}$ \\ ${ }^{1}$ Department of Chemistry, Dhenkanal College, Dhenkanal-759001, India \\ ${ }^{2}$ Department of Chemistry, VSSUT University, Burla, Sambalpur, India \\ ${ }^{3}$ Department of Chemistry, S. B Rath Government Women's (Auto) College, Berhampur, India \\ maildebasismohanty@gmail.com
}

Received 23 May2014 / Accepted 2 June 2014

\begin{abstract}
Three new chelating resins o-hydroxybenzaldehyde-2-aminothiazole-formaldehyde (o-HB-AT-HCHO), o-hydroxybenzaldehyde-6-methyl-2-aminobenzothiazole-formaldehyde (o-HB$\mathrm{MABT}-\mathrm{HCHO}$ ) and $o$-hydroxybenzaldehyde-6-chloro-2-aminobenzothiazole-formaldehyde (o-HBCABT-HCHO) having heterocyclic ring systems and multiple functional groups were synthesized by condensing the Schiff bases of $o$-hydroxybenzaldehyde-2-aminothiazole (o-HB-AT), $o$-hydroxybenzaldehyde-2-amino-6-methylbenzothiazole (o-HB-MABT) and $o$-hydroxybenzaldehyde-2-amino6-chlorobenzothiazole $(o-\mathrm{HB}-\mathrm{CABT})$ with formaldehyde. Their metal polychelate with $\mathrm{Cu}^{2+}, \mathrm{Ni}^{2+}$, $\mathrm{Fe}^{3+}$ and $\mathrm{UO}_{2}{ }^{2+}$ were prepared. The Schiff bases, resins and polychelates were characterized by various instrumental techniques like FTIR, ${ }^{1} \mathrm{H}$ NMR, TGA and DSC studies. These spectral and thermal studies provide very valuable information about the structural features, stability and crystallinity of the Schiff bases, resins and polychelates.
\end{abstract}

Keywords: Schiff base chelating resins, Metal ion uptake, Antibacterial activity

\section{Introduction}

Thiazole, substituted thiazoles and thiadiazole possess very interesting biological activity. This is probably due to the strong aromaticity of their ring system, which leads to great in vivo stability ${ }^{1}$ and also their five-membered heterocyclic rings are structurally similar to the imidazolyl moieties of the histidyl residue present in proteins ${ }^{2}$. Among thiazoles 2-aminothiazoles are heterocyclic amine with odor similar to pyridine, soluble in water, alcohol and ether. It is a beginning point for synthesis of many compounds including sulphur drugs, biocides, fungicides, dyes and chemical reaction accelerators. As ligands, they also provide many potential binding sites for complexation of diverse metal ions like $\mathrm{Cu}(\mathrm{II}), \mathrm{Co}(\mathrm{II})$, $\mathrm{Ni}(\mathrm{II})$, or $\mathrm{Zn}$ (II) among others with well established biological roles ${ }^{3-9}$. It is also a well known fact that aminothiazoles and aminothiazole Schiff bases have very good antibacterial, antiviral and anti fungal property and upon complexation with metal ions its antibacterial antiviral and antifungal properties increases many folds ${ }^{10-14}$. Therefore Schiff-bases of amino thiazoles and 
their transition metal complexes are found to be of great interest in co-ordination chemistry as well as pharmaceuticals chemistry ${ }^{15-18}$. The Schiff bases having multiple coordination sites are known to form complexes with transition metal ion readily ${ }^{19-21}$ present in a polymeric matrix they are expected to show affinity selectivity towards the metal ions at an appropriate $\mathrm{pH}$. This simple idea inspired our research group to synthesize a number of chelating resins containing Schiff base moiety and study their metal ion uptake behavior ${ }^{22-28}$. Literature studies reveal that metal ion uptake behavior of resins containing Schiff bases of heterocyclic compounds especially aminothiazole Schiff bases are yet to be studied and also there is no report of antibacterial activity of thiazole compounds present in a resin matrix.

In this paper, we report the synthesis of three phenol-formaldehyde type resins such as $o$-HB-AT-HCHO, $o$-HB-MABT-HCHO and $o$-HB-CABT-HCHO, by condensing Schiff bases obtained from $o$-hydroxybenzaldehyde and various aminothiazoles with formaldehyde. To ascertain the structural features of such indefinite phenol-formaldehydetype resins, a number of routine characterization techniques such as FTIR, ${ }^{1} \mathrm{H}$ NMR, TGA, and DSC studies were adopted. The idea is to use the resins simultaneously both for antibacterial activity and separation of heavy metal cations like $\mathrm{Cu}^{2+}, \mathrm{Ni}^{2+}, \mathrm{UO}_{2}{ }^{2+}, \mathrm{Co}^{2+}, \mathrm{Fe}^{3+}$ and toxic anions like $\mathrm{AsO}_{4}{ }^{3-}$ in drinking water. The metal ion uptake studies and arsenate uptake studies are presented else where. Here, along with synthetic details of Schiff base, resins and polychelates and their characterization, antibacterial activity of the resins against pathogenic bacteria like Escherichia coli and Staphylococcus aureus is reported. The synthetic methodology adopted here offers a new material which is expected to have widespread applications especially in the purification of drinking waters in rural regions which are contaminated with heavy metals and various pathogenic bacteria.

\section{Experimental}

The starting materials such as, 2-aminothiazole (Merck, Germany), 2-amino-6-methylbenozothiazole and 2-amino-6-chlorobenzothiazole were of Aldrich (USA). The $o$-hydroxybenzaldehyde, sulphate and nitrate salts of copper, nickel, uranyl and iron (Merck/BDH, India, AnalR grade) were used as received. Doubly distilled deionised water was used for the preparation of the solutions. The standard stock solution was prepared by dissolving an appropriate amount of $\mathrm{Cu}^{2+}, \mathrm{Ni}^{2+}, \mathrm{Fe}^{3+}$ and $\mathrm{UO}_{2}{ }^{2+}$ salts in deionised water. Working solutions were prepared by appropriate dilution of the stock solutions. The agar used for preparation of agar plate for antibacterial study was MacConkey Agar, Merck, Germany.

\section{Instrumentation}

The elemental analysis was carried out in a Carlo Erba 1108 elemental analyzer. A Waters Gel Permeation Chromatography equipment employing polystyrene as the reference standard was used to determine the molecular weight of the resins. The FTIR spectra in Bruker IFS 66v FTIR spectrometer in the range 4000-200 $\mathrm{cm}^{-1}$ in $\mathrm{KBr}$ phase. The ${ }^{1} \mathrm{H}$ NMR spectra were recorded in DMSO $d_{6}$ solvent in 400/300 MHz FT NMR (Bruker WM 400 / DRX 300) instruments. The TG (Du Pont 9900) and DSC (Du Pont 9900) of the materials were recorded up to $600 / 700{ }^{\circ} \mathrm{C}$ at a heating rate of $10{ }^{\circ} \mathrm{C} / \mathrm{min}$ in nitrogen atmosphere.

\section{Synthesis}

\section{Synthesis of Schiff bases}

The Schiff bases o-hydroxybenzaldehyde-2-aminothiazole, o-hydroxybenzaldehyde-2amino-6-methylbenzothiazole, o-hydroxybenzaldehyde-2-amino-6-chlorobenzothiazole were prepared by reacting 0.01 mole of the aminothiazoles dissolved in $10 \mathrm{~mL}$ of methanol 
with $1 \mathrm{~mL}(0.01$ mole) of $o$-hydroxybenzaldehyde in the presence of $0.5 \mathrm{~g}$ of anhydrous sodium acetate (Figure 1a). The mixture was refluxed for $6 \mathrm{~h}$ at $60-80{ }^{\circ} \mathrm{C}$, the contents poured into ice-cold water and allowed to stand for $24 \mathrm{~h}$. The precipitated solid were filtered off, washed repeatedly in demineralised water, recrystallized from methanol and dried at $80{ }^{\circ} \mathrm{C}$. The Schiff bases were isolated as yellow crystalline solids. The yields were more than $70 \%$.

\section{Synthesis of resins}

The phenolic Schiff base monomers $(1 \mathrm{~g})$ suspended in $20 \mathrm{~mL}$ water at $40{ }^{\circ} \mathrm{C}$ were dissolved by adding few drops of $1 \mathrm{M} \mathrm{NaOH}$. Paraformaldehyde in 1:2 molar ratios was added and the mixture was refluxed in an oil bath at $120-130{ }^{\circ} \mathrm{C}$ for $6-8 \mathrm{~h}$ (Figure $1 \mathrm{~b}$ ). The resins which often firmly adhered to the reaction vessel were scrapped into the solution and then filtered off, washed repeatedly with distilled water and dried at $70{ }^{\circ} \mathrm{C}$. The formaldehyde condensed resins (o-HB-AT-HCHO, o-HB-MABT-HCHO, and $o$-HB-CABT-HCHO) were isolated as insoluble solids (Figure 1c). o-Hydroxybenzaldehyde was also condensed with formaldehyde yielding $\mathrm{o}-\mathrm{HB}-\mathrm{HCHO}$ resins. This resin used as a control resin to compare various analytical details of the Schiff base resins.

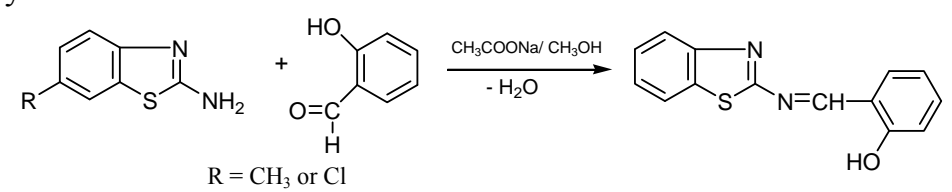

Figure 1(a) Reaction scheme for synthesis of Schiff base monomer.

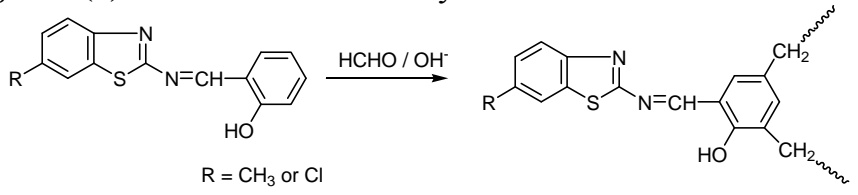

Figure 1(b) Reaction scheme for synthesis of resins.

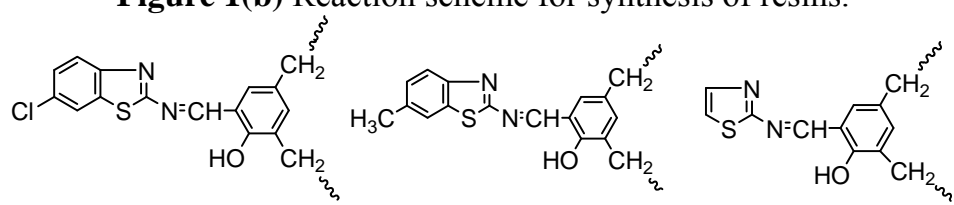

Figure 1(c). Structure of the, $o$-HB-AT-HCHO, o-HB-CABT-HCHO and $o$-HB-MABTHCHO resins

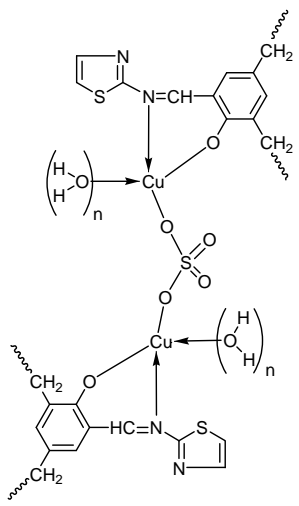

Figure 1(d). Structure of polychelates with bridging $\mathrm{SO}_{4}{ }^{2-}$ 


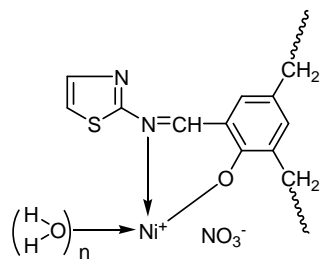

Figure 1e. $\mathrm{Ni}(\mathrm{II})$ polychelates showing $\mathrm{NO}_{3}{ }^{-}$as a counter anion

\section{Synthesis of polychelates}

To prepare the polychelates, $100 \mathrm{mg}$ of (100 mess, ASTM) dry resins (o-HB-AT-HCHO, o-HBMABT-HCHO, or $o$-HB-CABT-HCHO) were suspended over methanol. Metal salt solutions $\left(\mathrm{Cu}^{2+}, \mathrm{Ni}^{2+}, \mathrm{Fe}^{3+}\right.$ and $\mathrm{UO}_{2}{ }^{2+}$ with $\mathrm{SO}_{4}{ }^{2-}$ and/or $\mathrm{NO}_{3}^{-}$anions $)$were added $(0.15 \mathrm{M}$ in $10 \mathrm{~mL}$ water $)$ and the mixture was stirred for 5-6 h at room temp (Figure $1 \mathrm{~d} \& 1 \mathrm{e}$ ). It was seen that nearly after 30 minutes of continuous stirring the color of the mixture started changing due to complexation reaction between the ligands with metal ions. The insoluble solids were filtered off, washed in distilled water followed by petroleum ether and dried in vacuum at $70{ }^{\circ} \mathrm{C}$.

\section{Results and Discussion}

\section{FTIR Spectra}

In the FTIR spectra of Schiff base $o$-HB-AT, several characteristic absorption of starting materials (o-HB and 2-aminothiazoles) vanished and new absorption bands appeared. The carbonyl vibration of $o-\mathrm{HB}$ and the $\mathrm{N}-\mathrm{H}$ vibration of AT vanished. The $\mathrm{C}=\mathrm{N}$ stretch appeared as a sharp band at $1614 \mathrm{~cm}^{-1}$ along with the $\mathrm{C}=\mathrm{C}$ at 1497 and $1516 \mathrm{~cm}^{-1}$. The $\mathrm{C}-\mathrm{H}$ aromatic stretch appeared at $750 \mathrm{~cm}^{-1}$. Similar observation were also noted in case of $o$-HB-MABT and $o$-HB-CABT, where the $\mathrm{C}=\mathrm{N}$ stretch appeared as a sharp band at 1618.6 and $1640 \mathrm{~cm}^{-1}$ respectively.

In a control experiment, condensation of $o$ - $\mathrm{HB}$ with $\mathrm{HCHO}$ led to the resin $o$-HBHCHO. The FTIR spectrum of this resin was compared with the FTIR spectrum of the $o$-HB-AT-HCHO, o-HB-MABT-HCHO and o-HB-CABT-HCHO (Figure 2a and b). $o$-HB$\mathrm{HCHO}$ exhibited the characteristic carbonyl stretch as a sharp band at $1652 \mathrm{~cm}^{-1}$ (Figure 2a). In the FTIR spectrum of the aminothiazole Schiff base resins the $\mathrm{C}=\mathrm{N}$ absorption was seen in between 1606-1627 $\mathrm{cm}^{-1}$ as a prominent band. Several authors have reported the $\mathrm{C}=\mathrm{N}$ stretch of the Schiff base in the region ${ }^{29}$ of $1689-1471 \mathrm{~cm}^{-1}$. However, for these resins there was a relatively weak band at $\sim 1660 \mathrm{~cm}^{-1}$, characteristic of the aldehydic $\mathrm{C}=\mathrm{O}$ stretch. This band could be due to the hydrolytic cleavage of the $\mathrm{C}=\mathrm{N}$ bond of the Schiff base during condensation with $\mathrm{HCHO}$. However form the comparison of the areas of $\mathrm{C}=\mathrm{O}$ and $\mathrm{C}=\mathrm{N}$ in the FTIR spectrum (area calculation by paper weighing method repeated for 5 readings), it was found that less than $2 \%$ of the $\mathrm{C}=\mathrm{N}$ band suffered hydrolysis.

Complexation of the resin $o$-HB-MABT-HCHO with $\mathrm{Cu}(\mathrm{II})$ resulted in the shift of $\mathrm{C}=\mathrm{N}$ band by $18 \mathrm{~cm}^{-1}$ towards higher frequency region and the $\mathrm{Ph}-\mathrm{O}$ band did not shift from its original position in the resin and got diminished in intensity (Figure 2a). The spectra of the polychelates, $o$-HB-AT-HCHO-Cu(II) did not show any significant shift of $\mathrm{C}=\mathrm{N}$ and $\mathrm{Ph}-$ $\mathrm{O}$ vibrations. However the intensity of this peaks decrease sharply. In case of $o$-HB-CABT$\mathrm{HCHO}-\mathrm{Cu}(\mathrm{II})$ the $\mathrm{C}=\mathrm{N}$ shifted towards higher frequency region by $21 \mathrm{~cm}^{-1}$ and $\mathrm{Ph}-\mathrm{O}$ by $31 \mathrm{~cm}^{-1}$ towards lower frequency region. These observations are strong indications of efficient coordination through imine nitrogen and phenolic oxygen. Similar observations are also obtained for other metal polychelates. 


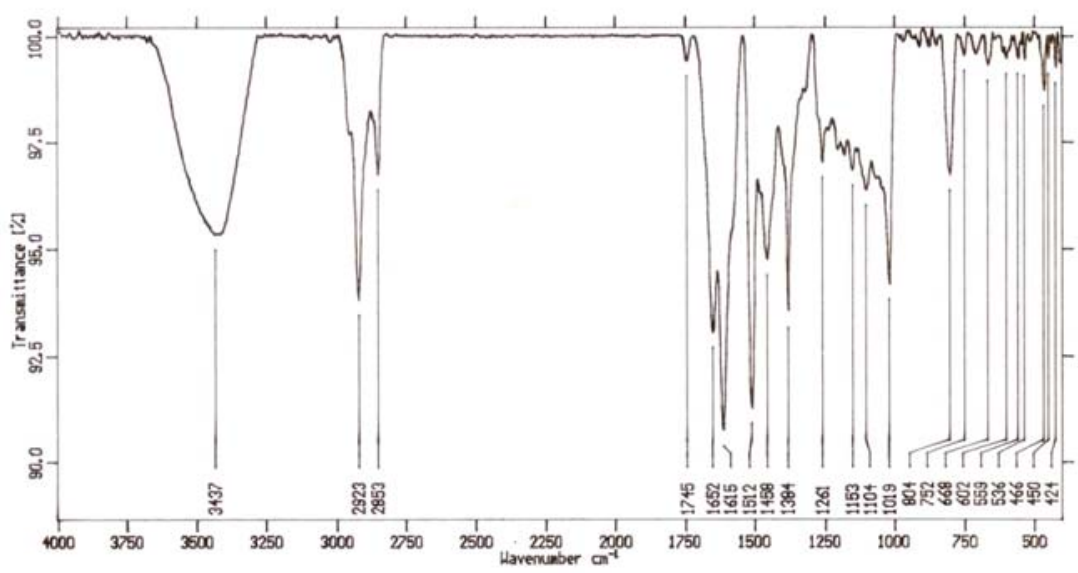

Figure 2(a). FTIR spectra of $o-\mathrm{HB}-\mathrm{HCHO}$ showing $\mathrm{C}=\mathrm{O}$ stretch at $1652 \mathrm{~cm}^{-1}$.

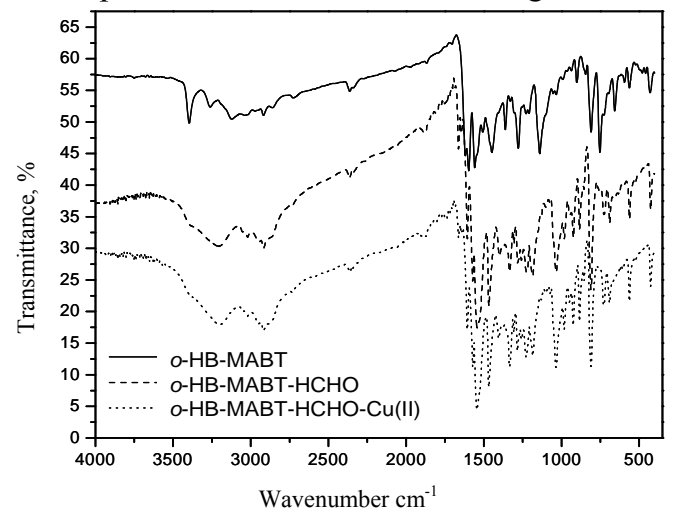

Figure 2(b). FTIR spectra of o-HB-MABT, o-HB-MABT-HCHO, o-HB-MABT-HCHO-Cu(II)

In addition, in the IR spectra of all three polychelates prominent absorption at $615-611 \mathrm{~cm}^{-1}$, $590-533 \mathrm{~cm}^{-1}$, assigned to $\mathrm{M}-\mathrm{O}$ and $\mathrm{M}-\mathrm{N}$ bonds respectively ${ }^{30,31}$. In addition to phenolic oxygen, imine nitrogen atoms are also binding the metal ions. The $\mathrm{C}=\mathrm{C}$ stretch which was registered respectively at 1516 and $1497 \mathrm{~cm}^{-1}$ in the resin and Schiff base, appeared at $1517 \mathrm{~cm}^{-1}$ in $\mathrm{Cu}^{2+}$ polychelates and 1600,1515 and $1475 \mathrm{~cm}^{-1}$ in $\mathrm{UO}_{2}{ }^{2+}$ polychelates as bands of sufficiently diminished intensity. This might indicate a decrease in $\pi$-electro density of aromatic ring consequent upon electron drift from the ring due to coordination of phenolic oxygen and imine nitrogen to the metal ion.

There was no $\mathrm{M}-\mathrm{S}$ band. It is thought that the lone pairs of ring sulphur and nitrogen have very less probability to take part in coordination. This can be explained as follows. The lone pair of electrons of the sulphur is involved in aromaticity of the ring and hence comparatively less available. Secondly the presence of an amino group at 2-position sterically hinders the attack of a Lewis acid on ring nitrogen and sulphur, thus making these donor sites less favorable for coordination. Similar observations were reported by Singh and coworkers ${ }^{32}$.

There is also evidence that, the counter anion sulphate acting as binding group between the metal ions. This conclusion is based on the characteristic modes of $\mathrm{SO}_{4}{ }^{2-}$ group vibrations ${ }^{33}$ at $1140-1080,1030$ and $980 \mathrm{~cm}^{-1}$. In case of $\mathrm{Ni}^{2+}, \mathrm{Fe}^{3+}$ and $\mathrm{UO}_{2}{ }^{2+}$ polychelates 
the $\mathrm{M}-\mathrm{O}$ and $\mathrm{M}-\mathrm{N}$ were not sharp and no significant shift was noticed. This observation is demonstrative of lower preference of these resins for $\mathrm{Ni}^{2+}, \mathrm{Fe}^{3+}$ and $\mathrm{UO}_{2}{ }^{2+}$ than $\mathrm{Cu}^{2+}$ ion. All the $\mathrm{Ni}^{2+}, \mathrm{UO}_{2}{ }^{2+}$ polychelates showed strong absorption at $1389 \mathrm{~cm}^{-1}$, which is characteristics of free nitrate ion of $\mathrm{Ni}\left(\mathrm{NO}_{3}\right)_{2}$ and $\mathrm{UO}_{2}\left(\mathrm{NO}_{3}\right)_{2}$ used for polychelate synthesis. Both the $\mathrm{Cu}^{2+}$ and $\mathrm{UO}_{2}{ }^{2+}$ polychelates showed absorption at $\sim 3400,900$ and $400 \mathrm{~cm}^{-1}$ indicating the presence of coordinating as well as lattice water ${ }^{34}$.

\section{${ }^{1}$ H NMR Spectra}

The ${ }^{1} \mathrm{H}$ NMR spectra of Schiff base and resins provided direct evidence for poly condensation reaction. The ${ }^{1} \mathrm{H}$ NMR spectra of Schiff base $o$-HB-AT and the resin $o$-HBAT-HCHO are presented in the (Figure $3 \mathrm{a} \& \mathrm{~b}$ ). In the Schiff base the azomethine proton $(\mathrm{CH}=\mathrm{N})$ was recorded at $8.91 \mathrm{ppm}$. A complex set of multiplets between 6.9 to $7.6 \mathrm{ppm}$ was due to coupling of the aromatic ring protons. The phenolic proton was not discernable as it merged with the aromatic proton peaks. Many authors assigned the position of $\mathrm{CH}=\mathrm{N}$ proton in the range 7.6 to $8.83 \mathrm{ppm}$ and phenolic proton at about $5.5 \mathrm{ppm}^{35,36}$.

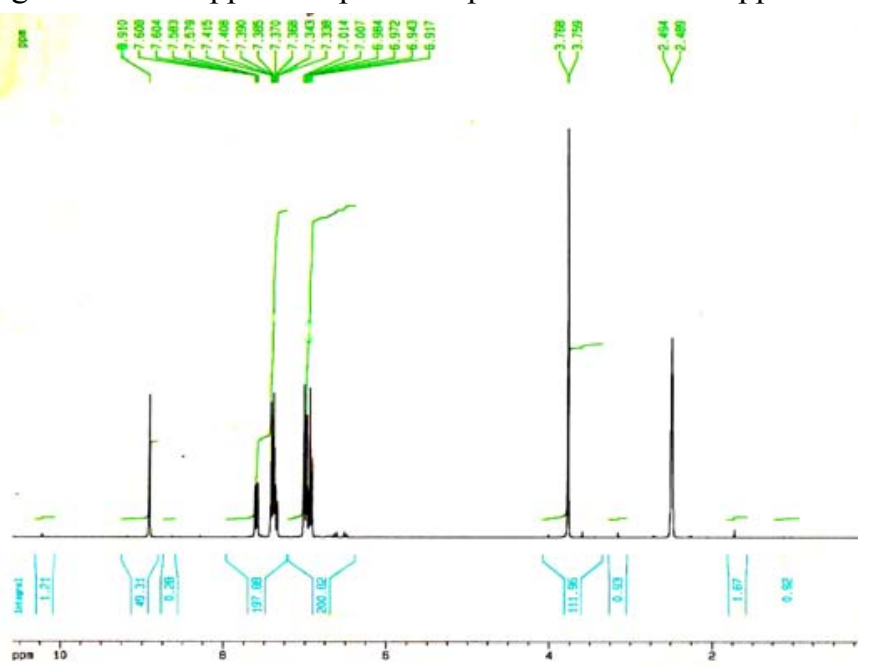

Figure 3a. ${ }^{1} \mathrm{H}$ NMR spectra of $o-\mathrm{HB}-\mathrm{AT}$ in the range $0-10 \mathrm{ppm}$

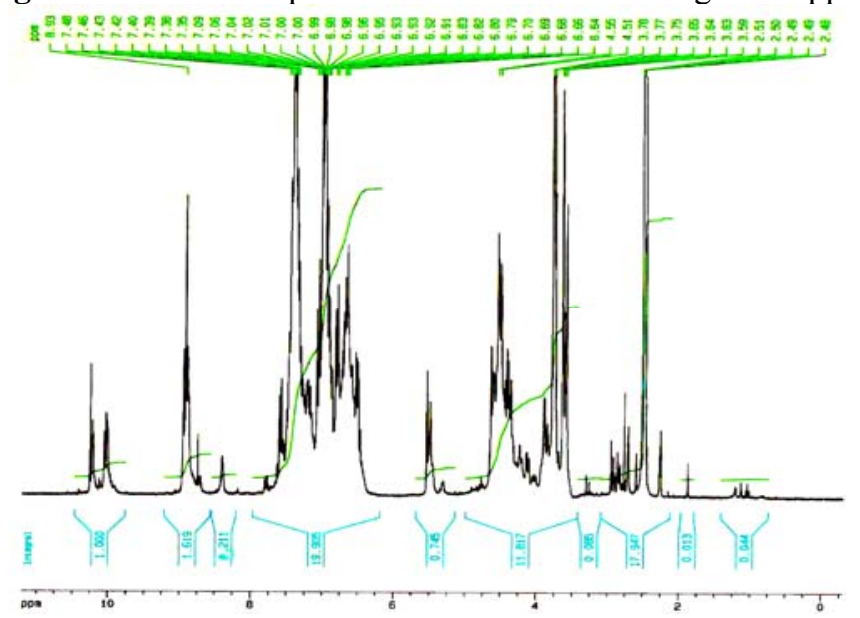

Figure 3b. ${ }^{1} \mathrm{H}$ NMR spectra of $o$-HB-AT-HCHO in the range $0-10 \mathrm{ppm}$ 
On condensation of the Schiff bases with formaldehyde, the aromatic ring protons appeared in the range 6.51-7.48 ppm as a broad multiplet and the azomethine proton did not change its position and appeared at $8.91 \mathrm{ppm}$. A number of additional peaks appeared in the range $3.534-3.887 \mathrm{ppm}$ and $4.10-4.641 \mathrm{ppm}$. These were assigned to the bridging methylene $\left(\Phi-\mathrm{CH}_{2}-\Phi\right)$ and methylene group and hydrogen bonded terminal methylol functions $\left(\Phi-\mathrm{CH}_{2}-\mathrm{OH}\right)$, respectively. The appearance of these peaks gives the evidence of polycondensation of the Schiff base, o-HB-AT with formaldehyde. Kizilcan and Akar have reported the ${ }^{1} \mathrm{H}$ NMR spectra of 16 chain extended cyclohexanone-formaldehyde and acetophenone-formaldehyde resins and assigned the peaks in the range 3.2-5.4 ppm to terminal $-\mathrm{CH}_{2}-\mathrm{O}-$ protons $^{37}$.

Similar observations are also noted in case of $o$-HB-MABT and $o$-HB-CABT Schiff base and their corresponding resins. In case the Schiff bases the azomethine proton $(\mathrm{CH}=\mathrm{N})$ was recorded between 8.2 to $9.3 \mathrm{ppm}$. The aromatic ring protons appeared in the range 6.9 to $7.9 \mathrm{ppm}$ as a set of complex multiplets. The phenolic proton was not discernable as it merged with the aromatic proton peaks.

The spectral pattern of Schiff bases of $o$-HB-MABT and $o$-HB-CABT after condensation with formaldehyde registered bridging methylene and terminal methylol function in the range 3.93-5.59 ppm for o-HB-MABT-HCHO, while in the range 4.9-5.4 for $o$-HB-CABT-HCHO. The phenolic $-\mathrm{OH}$ proton appeared at $\sim 5.6 \mathrm{ppm}$. The azomethine proton appeared as a singlet at $8.8 \mathrm{ppm}$ for $o$-HB-MABT-HCHO while at $9 \mathrm{ppm}$ for $o$-HB$\mathrm{CABT}-\mathrm{HCHO}$. The aromatic proton peaks became more complex and appeared as multiplets in the range 6.9 -7.6 ppm for 0 -HB-MABT-HCHO, while in the range 7.2-7.9 ppm for $o$-HB-CABT-HCHO. The complexity of the aromatic proton peaks in comparison to the Schiff base was due to the bridging methylene $\left.\Phi-\mathrm{CH}_{2}-\Phi\right)$ and the methylene group of hydrogen bonded terminal methylol functions $\left(\Phi-\mathrm{CH}_{2}-\mathrm{OH}\right)$ of the resins, which are the general characteristic of the phenol-formaldehyde type resins. The appearance of these peaks gives the evidence of polycondensation of the Schiff base with formaldehyde.

The spectra of the resins showed a weak aldehyde proton peak indicating that the Schiff base did partially suffer from hydrolysis under reaction condition set for polycondensation. But it was found that less than $2 \%$ of the $\mathrm{C}=\mathrm{N}$ band suffered hydrolysis.

\section{Thermal analysis}

\section{TG-DTG studies}

The TG traces of the resin, $o$-HB-AT-HCHO and the polychelate $o$-HB-AT-HCHO-Cu(II) are presented in (Figures $4 \mathrm{a} \& \mathrm{~b}$ ). Within $130{ }^{\circ} \mathrm{C}$, the resin lost $0.01 \%$ of its original weight whereas the polychelate lost $21.63 \%$ with a peak decomposition temperature at $83.06{ }^{\circ} \mathrm{C}$. Thus within $130{ }^{\circ} \mathrm{C}$, there was a significant weight loss for the polychelate, which could be ascribed mostly to the loss of small molecules such as methanol, the solvent which was used to synthesize the polychelate and adsorbed water molecules. Incorporation of metal ions into the resin matrix presumably led to adsorption of significantly higher number of water molecules as compared to the resin. These water molecules were loosely bound to the polymer matrix by weak valence forces as they were lost within about $130{ }^{\circ} \mathrm{C}$. Uma and coworkers studied thermal degradation of polymeric complexes of $\mathrm{Cu}(\mathrm{II}), \mathrm{Co}(\mathrm{II})$ and $\mathrm{Fe}(\mathrm{II})$ with poly(benzimidazoyl)acrylate-divinylbenzene copolymer ${ }^{38}$. The $\mathrm{Cu}(\mathrm{II})$ complex decomposed in a three stage process and they assigned the loss below 413-423 $\mathrm{K}$ to the elemination of water molecule as the crystal water and above $423 \mathrm{~K}$ to the water coordinated to metal ions in chelate. 


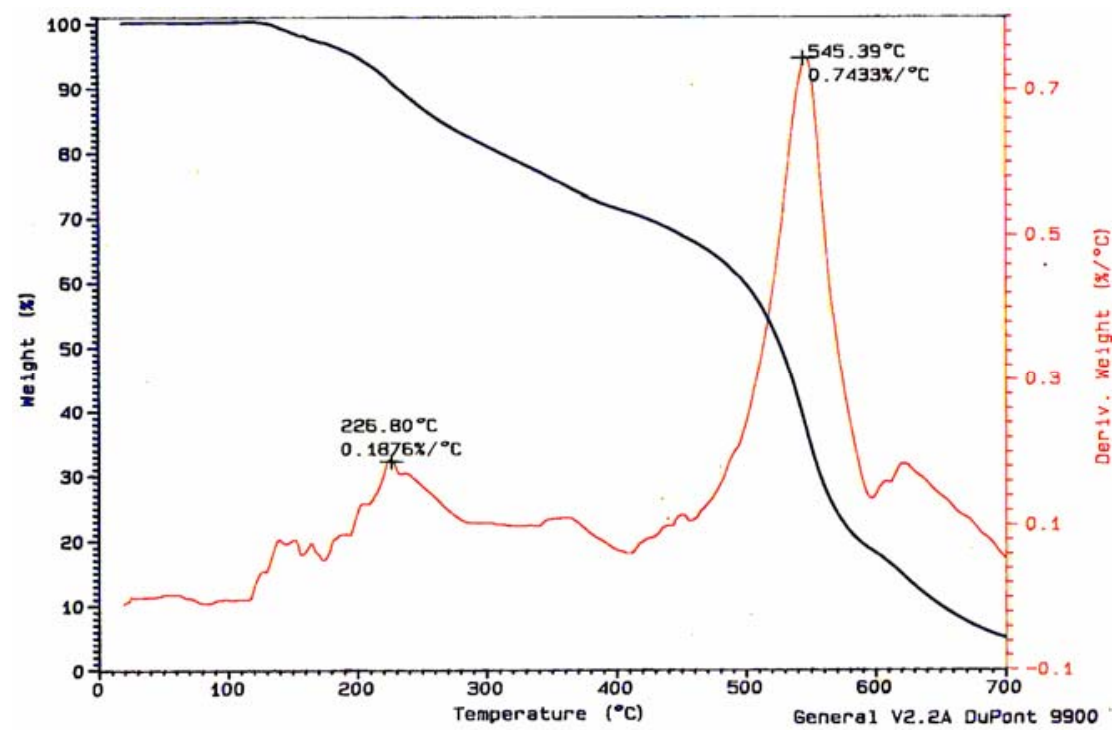

Figure 4a. TGA of $o$-HB-AT-HCHO

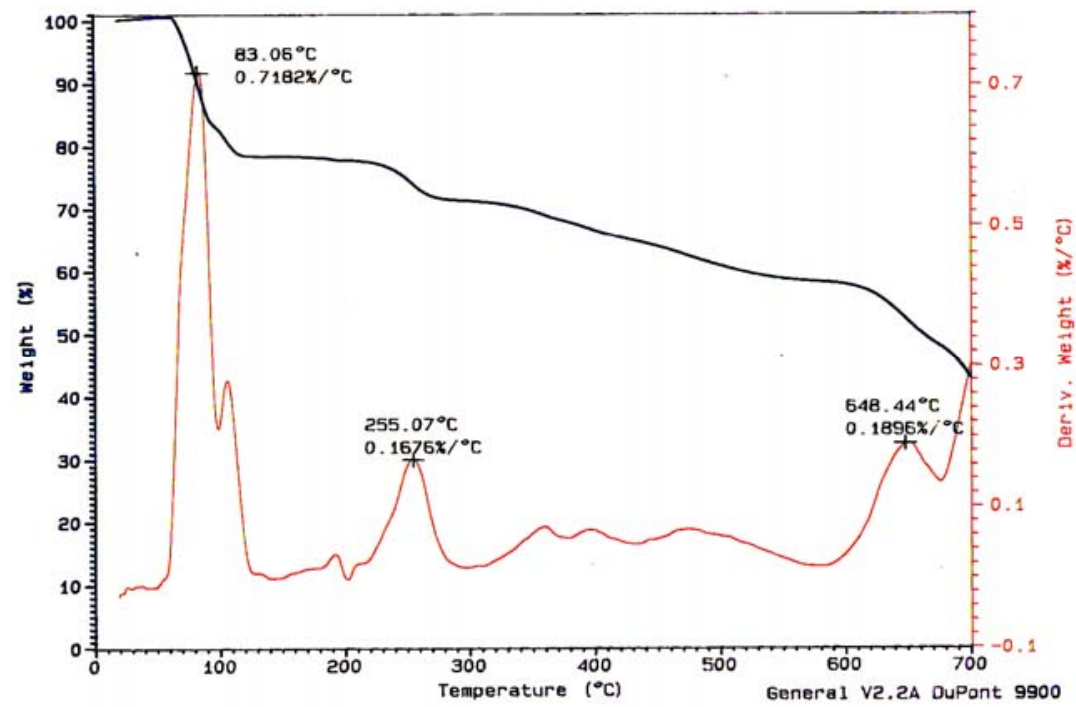

Figure $4 \mathbf{b}$. TGA of $o-H B-A T-H C H O-C u(I I)$

Between $130-200{ }^{\circ} \mathrm{C}$, the loss was not significant for both the resin and the polychelate. Between $200-600{ }^{\circ} \mathrm{C}$ resin lost $76.88 \%$ at a rapid rate. The temperature of maximum rate of weight loss, $\mathrm{T}_{\max }$, was $545.39{ }^{\circ} \mathrm{C}$, the rate of loss at this peak decomposition temperature being $0.7433 \% /{ }^{\circ} \mathrm{C}$. At $700{ }^{\circ} \mathrm{C}$ the char residue was as low as $4.94 \%$. The polychelate, on the other hand, lost only $19.95 \%$ between $200-600{ }^{\circ} \mathrm{C}$ and this too in a number of stages, at rates much lower as compared to the resin. The temperature of maximum rate of weight loss, $\mathrm{T}_{\max }$, between $200-600{ }^{\circ} \mathrm{C}$ were $255.07{ }^{\circ} \mathrm{C}$ and $548.44{ }^{\circ} \mathrm{C}$ and the rate of loss at this temperature were $0.1676 \% /{ }^{\circ} \mathrm{C}$ and $0.1896 \% /{ }^{\circ} \mathrm{C}$, respectively. The char yield at $700{ }^{\circ} \mathrm{C}$ was $42.80 \%$ ascribed to nonvolatile metal oxide. 
Similar observations were also observed for other two resins (o-HB-MABT and $o$-HB$\mathrm{CABT}$ ) and their polychelates. Polychelates were found to loose weight at a rapid rate early. In addition to solvent molecules adsorbed in the resin matrix, water molecules were present as coordinated to the metal ions, which were lost easily. The TG-DTG traces exhibited unique features in that most of the resins were found to be more stable than their corresponding polychelates.

It was thus observed that the polychelate suffered rapid decomposition at lower temperatures. Beyond $130{ }^{\circ} \mathrm{C}$, the rate of weight loss for the polychelate was slower than that of the resin. Nevertheless, the easy desorption of small loosely bound molecules from the polychelate matrix at low temperatures affected the over all stability of the polychelate. Incorporation of metal ion into the resin matrix, thus, led to a decrease in the thermal stability. Oriel et al., supports the present finding ${ }^{39}$. Characteristics such as the nature of the polymer backbone and the extent of cross-linking are known to influence the thermal stability of polymer-metal complexes. In addition, the molecular structure, which decides the metal content, is also a determining factor. On supply of thermal energy the resins get crossed linked, which was presumably less effective in the presence of adsorbed metal ion ${ }^{40}$. The metal ion would also catalyze the thermal decomposition of the resin at higher temperatures $^{41}$.

\section{DSC Studies}

The DSC scan of the resin $o$-HB-AT-HCHO showed an endotherm with onset temperature at $199.04{ }^{\circ} \mathrm{C}$ and a peak minimum at $200.15{ }^{\circ} \mathrm{C}$ (Figure $5 \mathrm{a} \& \mathrm{~b}$ ). In this temperature range, the TG trace shows a small mass loss. Hence, the endotherm could be curing of the resin manifested by loss of water molecules. Curing is known to a characteristic of phenolformaldehyde resins. The melting was not observed. After curing temperature, the resin continued to absorb thermal energy and exothermic decomposition reactions set in.

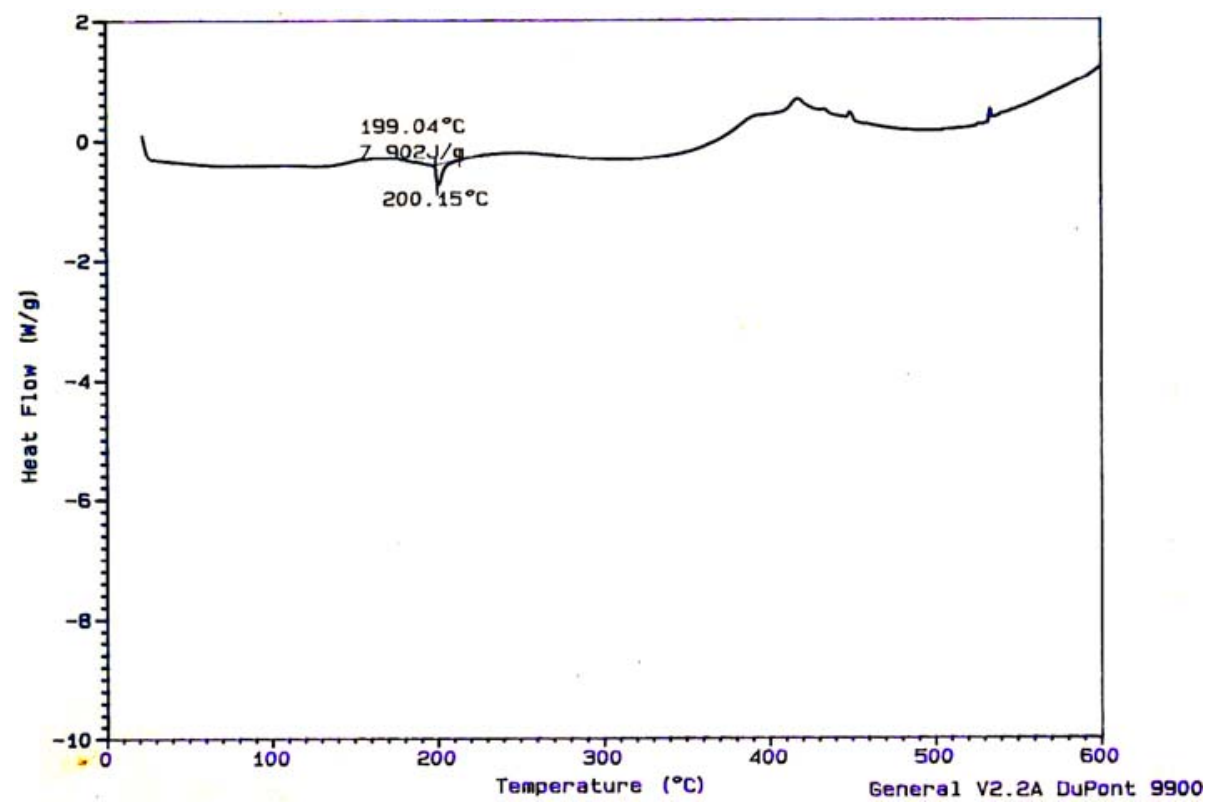

Figure 5a. DSC of $o$-HB-AT-HCHO 


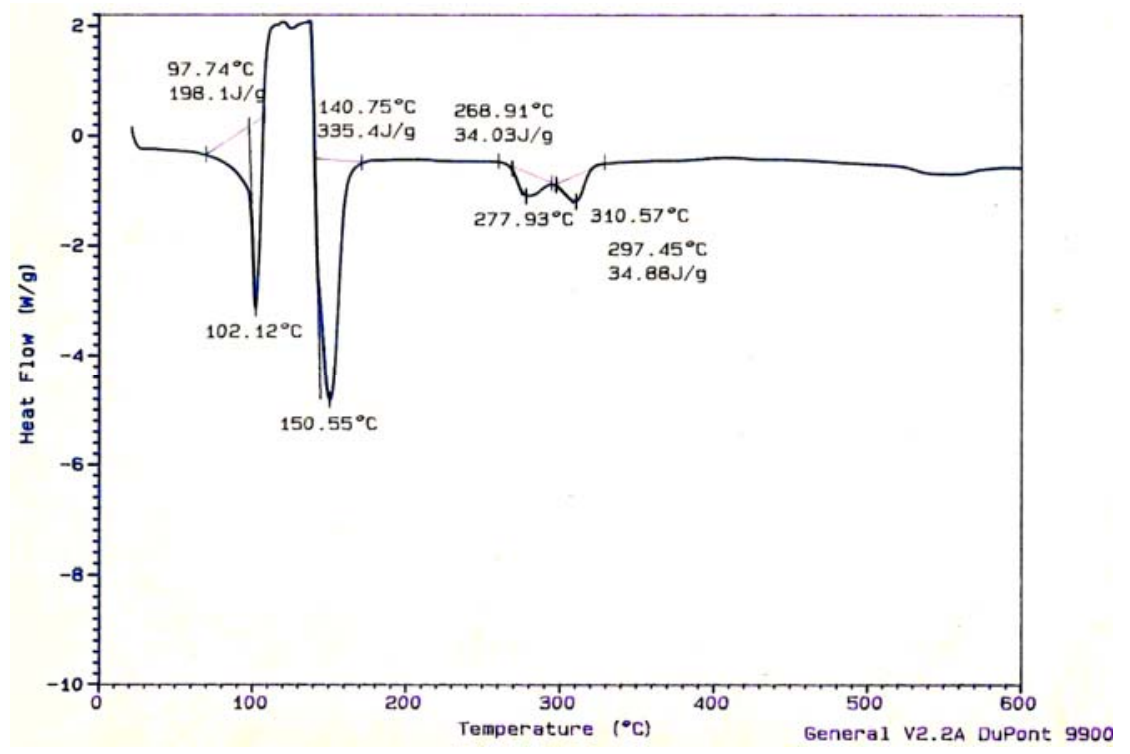

Figure 5b. DSC of $o$-HB-AT-HCHO-Cu(II)

The polychelate registered two sharp endothermic transitions closely placed with minima at $102.12,150.55^{\circ} \mathrm{C}$. In this temperature, as seen in the TG trace, there was rapid loss of loosely bound solvent molecules. The endothermic could be ascribed to these loses with accompanying phase changes. A second endotherm was set in from $268.91{ }^{\circ} \mathrm{C}$ with a minima at $277.93{ }^{\circ} \mathrm{C}$ and end set at $297.93{ }^{\circ} \mathrm{C}$. The polychelate possessed appreciable crystallinity indicated by the sharp melting temperature at $310.57{ }^{\circ} \mathrm{C}$.

Similar observations were also observed for other two resins (o-HB-MABT and o-HB$\mathrm{CABT}$ ) and their polychelates. The $\mathrm{Cu}(\mathrm{II})$ polychelate showed several endothermic peaks within $200{ }^{\circ} \mathrm{C}$ pertaining to the desorption of solvents and consequent phase changes. The polychelates registered sharp melting temperatures indicating significant increase in crystallinity over that of the corresponding resins.

\section{Conclusion}

Phenolic Schiff bases containing aminothiazole moiety were synthesized. Condensation polymerization of these multifunctional phenolic Schiff bases with formaldehyde was successfully carried out. In attempting to draw a conclusion about the structural features of such indefinite phenol-formaldehyde-type polymers, a number of routine characterization techniques such as FTIR, ${ }^{1} \mathrm{H}$ NMR, TG-DTG, and DSC studies were adopted. FTIR studies indicate that in the course of polycondensation the $\mathrm{C}=\mathrm{N}$ bonds remained intact to a large extent. In the FTIR spectra there were distinct shifts of $\mathrm{C}=\mathrm{N}$ and $\mathrm{Ph}-\mathrm{O}$ vibrations from their respective positions in the resin following coordination, indicating that the imine nitrogen and the phenolic oxygen are the sites for binding the metal ions. The ${ }^{1} \mathrm{H}$ NMR spectra of the Schiff bases and resins provided direct evidence for polycondensation reaction. In all the resins the azomethine proton $(\mathrm{CH}=\mathrm{N})$ was recorded between 8.2 to 8.91 ppm. All the resins also registered well defined bridging methylene proton and terminal methylol functions. The appearance of these peaks gives the evidence of polycondensation of the Schiff base with formaldehyde. The TG-DTG traces exhibited unique features in that most of the resins were found to be more stable than their corresponding polychelates. 
This observation was further supported by the evaluation of the kinetic energy of thermal decomposition reactions using several integral methods. Analysis of the DSC data of the resins and the polychelates provided a number of complimentary features. All the $\mathrm{Cu}$ (II) polychelates showed several endothermic peaks within $200{ }^{\circ} \mathrm{C}$ pertaining to desorption of solvents and consequent phase changes. The polychelates registered sharp melting temperatures indicating significant increase in crystallinity over that of the corresponding resins. The synthetic methodology adopted here offers a new material which is expected to have widespread applications especially in the purification of drinking waters in rural regions which are contaminated with heavy and toxic metals and various pathogenic bacteria. These materials is also is expected to be very effective separation of valuable or toxic metals from hydrometallurgical liquids and industrial effluents.

\section{Acknowledgement}

The authors wish to acknowledge various RSICS for providing their analytical and library facilities. The Principal, Dhenkanal (Auto) college is highly acknowledged for providing facilities to carry out the work..

\section{Reference}

1. Komis G, in Comprehensive Heterocyclic Chemistry, Katritzky A R, Ed., Pergamon New York, 1984, Vol. 6, Part 4B.

2. Kornis G, 1,3,4-Thiadiazoles, in Comprehensive Heterocyclic Chemistry, Katritzky A R, Ed., Pergamon, New York, 1984, Vol. 6, Part 4B, p 545.

3. Johnson D K, Murphy T B, Rose T B, Goodwin W H and Pickart L, Inorg Chim Acta, 1982, 67, 159-166; DOI:10.1016/S0020-1693(00)85058-6

4. Alzuet G, Ferrer S, Borras J and Supuran C T, Roum Chem Quart Rev., 1994, 2(4), 283-300.

5. Supuran C T and Almajan G L, Main Group Met Chem., 1995, 18, 347-351.

6. Supuran C T, Met Based Drugs, 1995, 2, 331-336; DOI:10.1155/MBD.1995.331

7. Supuran C T and Scozzafava A, J Enz Inhib., 1997, 12(1), 37-51.

8. Alzuet G, Casanova J, Borras J, Garcia-Granda S, Gutierrez-Rodriguez A and Supuran C T, Inorg Chim Acta, 1998, 273(1-2), 334-338;

DOI:10.1016/S0020-1693(97)06020-9

9. Chohan Z H, Jaffery M. F and Supuran C T, Met Based Drugs, 2001, 8(2), 95-101; DOI:10.1155/MBD.2001.95

10. Chohan Z H and Kausar S, Met Based Drugs, 2000, 7(1), 17-22; DOI:10.1155/MBD.2000.17

11. Chohan Z H, Pervez, H, Rauf A, Scozzafava A, Claudiu T and Supuran C T, $J$ Enzyme Inhib Med Chem., 2002, 17(2), 117-122.

12. Vukovic N, Sukdolak S, Solujic S and Milosevic T, Arch Pharm Chem Life Sci., 2008, 341(8), 491-496; DOI:10.1002/ardp.200700215

13. Chohan Z H and Praveen M, Appl Organomet Chem., 2000, 14(6), 376-382; DOI:10.1002/1099-0739(200007)14:7<376::AID-AOC995>3.0.CO;2-5

14. Chohan Z H, Met Based Drugs, 1999, 6(2), 75-90; DOI:10.1155/MBD.1999.75

15. Hills A, Hughes D L, Leigh G J and Sanders J R, J Chem Soc Dalton Trans., 1991, 325.

16. Knoch R, Wilk A, Wannowius K J, Reinen D and Elias H, Inorg Chem., 1990, 29(19), 3799-3805; DOI:10.1021/ic00344a030

17. Carbonaro L, Giacometti A, Senatore L and Valli L, Inorg Chim Acta, 1989, 165(2), 197-200; DOI:10.1016/S0020-1693(00)83239-9 
18. Bottino F A, Finocchiaro P and Libbertini E, J Coord Chem., 1988, 16(4), 341-345; DOI: $10.1080 / 00958978808081660$

19. Ueno K and Martell A E, J Phys Chem., 1955, 59, 998.

20. Ueno K and Martell A E, J Phys Chem. 1956, 60, 1270.

21. Che C M and Cheng W K, J Chem Soc Chem Commun., 1986, 1443-1444; DOI: $10.1039 / \mathrm{C} 39860001443$

22. Samal S, Ray A R, Dey R K and Acharya S, Indian J Chem Technol., 2004, 11, 695-703.

23. Samal S, Acharya S, Dey R K and Ray A R, Talanta, 2002, 57(6), 1075-1083; DOI:10.1016/S0039-9140(02)00144-3

24. Samal S, Das R R, Acharya S, Mohapatra P and Dey R K, Polym Plast Technol Eng., 2002, 41(2), 229-246; DOI:10.1081/PPT-120002565

25. Samal S, Mohapatra N K, Acharya S and Dey R K, React Funct Polym., 1999, 42(1), 37-52; DOI:10.1016/S1381-5148(98)00055-8

26. Samal S, Das R R, Dey R K and Acharya S, J Appl Polym Sci., 2000, 77(5), 967-981; DOI:10.1002/1097-4628(20000801)77:5<967::AID-APP3>3.0.CO;2-5

27. Samal S, Acharya S, Mohapatra P and Dey R K, Res J Chem Environ., 2000, 4(3), 11-25.

28. Chohan Z H and Rauf A, Synth React Inorg Met-Org Chem., 1996, 26(4), 591-604; DOI:10.1080/00945719608004764

29. Silverstein R M, Bassler G C and Morrill T C, in Spectrometric Identification of Organic Compounds, Fourth Edition, 1981, John Wiley, New York, p-130.

30. Bajpai U D N, Rai S and Bajpai A, J Appl Polym Sci., 1993, 48(7), 1241-1248; DOI:10.1002/app.1993.070480712

31. Ueno K and Martell A E, J Phys Chem., 1956, 60, 1270-1275.

32. Singh P P and Srivastava A K, J Inorg Nucl Chem., 1974, 36(4), 928-930; DOI:10.1016/0022-1902(74)80839-0

33. Nakamato K, Fujita J, Tanaka S and Kobayaski M, J Am Chem Soc., 1957, 79(17), 4904-4908; DOI:10.1021/ja01575a020

34. Chiang W Y and Mei W P, Eur Polym J., 1993, 29(8), 1047-1051; DOI:10.1016/0014-3057(93)90307-2

35. Antony R and Pillai C K S, J Appl Polym Sci., 1994, 54(4), 429-438; DOI:10.1002/app.1994.070540403

36. Hafi N, Kolli M, Vergnaud J M and Montheard J P, J Appl Polym Sci., 1991, 43(10), 1837-1847; DOI:10.1002/app.1991.070431007

37. Kizilcan N and Akar A, J Appl Polym Sci., 1998, 70(4), 655-663; DOI:10.1002/(SICI)1097-4628(19981024)70:4<655::AID-APP4>3.0.CO;2-P

38. Uma M, Prabhakar L D, Dalanivelu C B and Tharickachalam V, Proceeding of $8^{\text {th }}$ National Symposium on Thermal Analysis, Dec, 19-21, (1991), RRL, Bhubaneswar (India).

39. Oriol L, Alonso P J, Martineoz I J, Pinol M and Serrano J L, Macromolecules, 1994, 27(7), 1869-1874; DOI:10.1021/ma00085a031

40. Upedegraff I H and Suen T J, 'Condensation with Formaldehyde', Chap. 14 in 'Polymerization Process', Schildknecht, C. E.; Skeist, I. Ed., 1997, WileyInterscience, New York.

41. Samal S, Das R R, Sahoo D and Acharya S, Polym International, 1997, 44(1), 41-48; DOI:10.1002/(SICI)1097-0126(199709)44:1<41::AID-PI803>3.0.CO;2-\# 